FEDERAL RESERVE BANK OF SAN FRANCISCO

WORKING PAPER SERIES

\title{
How Have Borrowers Fared in Banking Mega-mergers?
}

\author{
Kenneth A. Carow \\ Indiana University \\ Edward J. Kane \\ Boston College \\ Rajesh P. Narayanan \\ Ohio University
}

March 2005

Working Paper 2005-09

http://www.frbsf.org/publications/economics/papers/2005/wp05-09bk.pdf

The views in this paper are solely the responsibility of the authors and should not be interpreted as reflecting the views of the Federal Reserve Bank of San Francisco or the Board of Governors of the Federal Reserve System. 


\title{
How Have Borrowers Fared in Banking Mega-mergers?
}

\author{
Kenneth A. Carow \\ Indiana University \\ Kelley School of Business - Indianapolis \\ 801 W. Michigan Street \\ Indianapolis, IN 46202-5151 \\ Email: kcarow@iupui.edu \\ Phone: (317) 274-2783 \\ Fax: (317) 274-3312
}

\author{
Edward J. Kane \\ Boston College \\ Fulton Hall 330A \\ Chestnut Hill, MA 02467 \\ Email: edward.kane@bc.edu \\ Phone: (617) 552-3986 \\ Fax: (617) 552-0431
Rajesh P. Narayanan
Ohio University 230 Copeland Hall
Athens, OH 45701 \\ Email: narayana@ohio.edu \\ Phone: 740-593-2089 \\ Fax: 740-593-9539
}




\title{
HOW HAVE BORROWERS FARED IN BANKING MEGAMERGERS?
}

\author{
KENNETH CAROW
}

EDWARD J. KANE

RAJESH NARAYANAN

\begin{abstract}
:
Previous studies of event returns surrounding bank mergers show that banks gain value in megamergers and additional value when they absorb in-market competitors. A portion of these gains has been traced to the increased bargaining power of banks vis-àvis regulators and other competitors. We demonstrate that increased bargaining power of megabanks adversely affects loan customers of the acquired institution. Wealth losses are greater when loan customers are credit-constrained, the loan customer is smaller, or the acquisition is an in-market deal. These findings reinforce complaints that the ongoing consolidation in banking has unfavorably affected the availability of credit for smaller firms and especially capital-constrained firms.
\end{abstract}




\section{HOW HAVE BORROWERS FARED IN BANKING MEGAMERGERS?}

Previous studies of event returns surrounding bank mergers show that banks gain value in megamergers and additional value when they absorb in-market competitors. A portion of these gains has been traced to the increased bargaining power of banks vis-à-vis regulators and other competitors. We demonstrate that increased bargaining power of megabanks adversely affects loan customers of the acquired institution. Wealth losses are greater when loan customers are credit-constrained, the loan customer is smaller, or the acquisition is an in-market deal. These findings reinforce complaints that the ongoing consolidation in banking has unfavorably affected the availability of credit for smaller firms and especially capitalconstrained firms.

\section{Introduction}

Differences in relative bargaining power inevitably affect the outcome of bilateral negotiations. In banking, bargaining takes place in three arenas: between banks and their regulators; between banks and their customers; and between acquiring institutions and target firms. This paper uses event-study methods to investigate how presumptive changes in the balance of bargaining power engendered by merger announcements affect the benefits and costs that corporate customers are expected to encounter in dealing with an enlarged megabanking firm.

Gains in mergers arise either through efficiency improvements or through increases in market power (Focarelli, Panetta and Salleo, 2002). Although bank merger announcements routinely project subsequent improvements in efficiency and diversification, statistically significant net increases in the market capitalization of the combining banks seldom occur. The value of the target stock usually increases, but this increase typically occurs at the expense of the acquirer's stock value (Houston and Ryngaert, 1994; Houston, James and Ryngaert, 2001).

However, mergers involving megabanks show a different pattern. The stock of megabank acquirers typically gains value when the acquirer announces an acquisition. Moreover, the benefit increases with target size and is larger when the target was previously competing in-state (Kane, 2000). Kane hypothesizes that megamerger gains arise in part from improved access to monopoly rents and regulatory subsidies. Whatever scale and scope economies might exist in production and distribution costs, mergers eliminate an actual or potential competitor, while increased size strengthens market presumptions that the institution is both Too-Big-to-Fail (TBTF) and, in future disputes with customers and regulators, "Too big to Discipline Adequately" (TBTDA). Resulting increases in the market power of the bank and in the intangible value of the government's 
credit enhancement lower its funding costs and increase its market capitalization. Evidence that mergers enhance the value of bank debt (Penas and Unal, 2004) supports this interpretation.

How megabank mergers affect the expected financing costs of established loan customers is the econometric focus of this paper. On the one hand, any newfound efficiencies in loan production and contracting might translate into lower borrowing costs, while the increased political clout of the post-merger entity would lessen the chance that its failure could force a longtime borrower to lose its intangible investment in favorable ties with bank officers. Looking at the 1984 collapse and subsequent rescue of Continental Illinois Bank, Slovin, Sushka, and Polonchek (1993) provide evidence that customers' wealth falls and rises with fluctuations in their lending institution's financial health. In studies of banking problems in Japan, Korea, and Norway, Brewer et al (2003), Bae, Kang and Lim (2002) and Ongena, Smith and Michalsen (2003) respectively show that bank problems and failures reduced borrower stock prices, especially for more dependent and poorer-performing loan customers

On the other hand, mergers threaten to hurt at least some customers and can do so in three ways. First, post-merger staffing cuts may displace some (or all) of the particular officers whose favor the customer had previously cultivated. Surviving loan officers are unlikely to be aware of every important contact the customer has previously had with one partner or the other. Second, in eliminating a competitor the merger may curtail some customers' bargaining power. Lastly, an enhanced government guarantee would shift risk to the customer in its capacity as a taxpayer.

Studies of bank mergers in Norway, Belgium, and Italy indicate that bank mergers affect customer stock prices, relationship exit rates, and credit costs respectively. Karceski, Ongena, and Smith (2004) find that Norwegian bank merger announcements reduce the equity value of small publicly traded firms that are target customers. Consistent with the hypothesized joint effect of large in-market mergers on competitive pressure and of reduced competitive pressure on customer bargaining power, the decline increases with the size of the target bank. In the Norwegian environment, the stock prices of relationship customers of the acquiring bank increase. 
A relationship customer is one that enjoys a history of successful contacts with a bank. Following Belgian bank mergers, Degryse, Masschelein and Mitchell (2003) find that target customers are more likely than acquirer customers to have their relationships terminated with their bank. These effects are more pronounced for smaller customers with no alternate lending relationships. In Italy, Sapienza (2002) finds that, contract interest rates on bank loans fall when banks with small shares of the local banking market combine. The contrary result is observed for mergers of large Italian banks. This differential finding for large and small bank mergers is consistent with the joint hypothesis that economies of scale exist only for very small banks and that, only when markets are competitive, are merger benefits shifted into loan rates.

These findings are consistent with studies that indicate that at the margin, after banks reach a threshold asset size, they channel an increasing proportion of the lending to large firms. This pattern implies that megabank mergers threaten to disrupt the availability of credit to small businesses. Studies by Strahan and Weston (1998) and Berger, Saunders, Scalise, and Udell (BSSU, 1998) support these concerns. Strahan and Weston find that, as a proportion of bank assets, small-business lending increases only when the merging banks are both small, while mergers between medium and large institutions do not noticeably move this proportion. BSSU find that small-business lending increases following a merger of small banks, but decreases when large banks combine.

A 2004 survey by the Association of Finance Professionals manitfests similar concerns in the United States. Nearly two-thirds of the surveyed chief financial officers and treasurers at companies with revenues of $\$ 1$ billion or more said a bank had denied credit or raised loan prices because the corporate executive did not buy additional services. Executives attribute this to the "growing clout and competition in the banking industry that have come with consolidation and the repeal of laws separating the banking and brokerage business" (Sapsford 2004).

To investigate how the sign of the net effect varies with merger characteristics and customer circumstances, this study estimates whether and how merger announcements for the ten largest domestic U.S. bank mergers between 1991 and 2001 affect the value of intangible customer relationships at target and acquiring banks. On 
average, the stock prices of established corporate customers show no statistically significant announcement effect. However, once we control for salient merger and customer characteristics, significant effects emerge. These effects are consistent with the hypothesis that megamergers consolidate market power in particular market segments. On average, target customers suffer in all four mergers where the partners show substantial geographic overlap. As predicted by the bargaining-power hypothesis, very large customers are undamaged and smaller customers of targets fare especially badly when the announcement indicates that managers of the target firm are not going to be treated as equal partners. Finally, losses prove most severe for customers that show evidence of being credit-constrained.

The paper has four sections. Section II summarizes the economics of bankcustomer relationships and lays out some testable hypotheses. Section III reviews the construction and properties of our dataset. Section IV outlines the methodology and Section V presents the results. Section VI concludes with a discussion of policy implications and opportunities for future research.

\section{Sources and Distribution of Intangible Value in Bank-Customer Relationships}

Modern banking theory emphasizes that the many and repeated points of contact a bank has with its established customers generate private information and mutual trust. Diamond's delegated-monitoring hypothesis holds that banks either win access to inside information from good customers or uncover such information through analysis they undertake in the course of supporting and observing their customers' loan and deposit business (Diamond, 1984; Kane and Malkiel, 1965).

Privileged information and a climate of mutual trust allow a bank to assess and price the risk of lending to a relationship customer more accurately than the bank's competitors can. In principle, abilities or capacities that create such extranormal returns are intangible assets. In each relationship, the relevant intangible asset may be portrayed as a mutual claim to the capitalized value $(\mathrm{R})$ of the reduced opportunity costs. The outcome of a bilateral bargaining process (BP) allocates $\mathrm{R}$ partly to the relationship customer $\left(\mathrm{R}_{\mathrm{C}}\right)$ and partly to the bank $\left(\mathrm{R}_{\mathrm{B}}\right)$ :

$$
\mathrm{R}_{\mathrm{C}}(\mathrm{BP})+\mathrm{R}_{\mathrm{B}}(\mathrm{BP})=\mathrm{R}(\mathrm{BP}) .
$$


Because $R$ requires the cooperation of both parties, equilibrium $R_{C}$ and $R_{B}$ should each be strictly positive to avoid outcomes that would eliminate the counterparty's incentive to renew the relationship.

To derive testable hypotheses about the determinants of the intangible values $R_{C}$ and $\mathrm{R}_{\mathrm{B}}$, we can model $\mathrm{R}$ and the differences in bargaining power as functions of a series of observable bank, borrower, and merger characteristics that might reasonably be expected to affect their relative bargaining power. Given R, the impact of a megamerger on a customer's $\mathrm{R}_{\mathrm{C}}$ depends on whether and how particular bank and merger characteristics might alter its bargaining power. The customer's bargaining power increases with its size and the extent to which the importance of the officers that have handled its business in the past promise to survive post-merger reorganization activity and decreases if the merger is expected to curtail the customer's ability to tap alternative sources of credit on fair terms.

\section{Dataset Construction and Description}

\section{a. Sample construction}

Our sampling procedure imposes four screens. First, we see ourselves as sampling from the universe of loan customers whose banks happened to participate in each of the ten largest combinations of U.S. domestic banks during 1991-2001.

In identifying bank relationships, Gande et al. (1997) and Narayanan et al. (2004) include all member banks in a lending syndicate. However, Yasuda (2005) demonstrates that bank relationships are better characterized by considering only lead lenders in the lending syndicate. Following Yasuda, we identify "relationship" customers as firms for which one or both combining banks served as a sole lender or lead lender in a syndicate at the time of the merger announcement using Loan Pricing Corporation's (LPC) Dealscan database. ${ }^{1}$

\footnotetext{
${ }^{1}$ The Dealscan database provides details of loans over $\$ 100,000$ compiled from 13Ds, 14Ds, 13Es, 10Ks, $10 \mathrm{Qs}, 8 \mathrm{Ks}$, and S-series (registration) documents that publicly held companies and those privately held companies with public debt outstanding file with the Securities Exchange Commission. Lead lenders in syndicated loans are identified from the LPC Dealscan database if the bank's role in the syndicate is characterized by titles such as arranger, co-arranger, administrative agent, agent or co-agent. Lead lenders typically hold the largest stakes in the loan syndicate and perform the origination and monitoring roles associated with the loan syndicate.
} 
Identifying firms which have outstanding credit facilities with the combining banks in each merger and aggregating over the ten mergers produces 6,823 firm observations involving 4,718 unique firms. ${ }^{2}$ From these observations, we sample only those customers that meet the following data-availability restrictions:

1. have daily returns available on $C R S P$ during and 210 days prior to the announcement window (produces 3,667 firm observations);

2. have balance sheet and income statement data on Compustat (produces 2,677 firm observations);

3. have observations whose SIC code $(=6)$ does not classify them as financial firms (produces 2,325 firm observations);

4. have observations that are traded at least $30 \%$ of the designated estimation period trading days and whose event returns did not exceed 15 percent in absolute value (produces the final sample of 2,204 firm observations).

Financial companies are eliminated on the grounds that abnormal returns for these customers may be contaminated by changes in their prospects as competitors of the proposed mega-institution. The other sample reductions lessen distortions associated with nonsynchronous trading, the concurrent release of important idiosyncratic information, and potential outliers.

\section{b. Variable definitions}

\section{Merger and Market Characteristics}

Takeovers raise "issues" of governance, whose resolution can be more or less friendly to target management. As Table 1 indicates, SNL DataSource characterizes six of the ten megadeals as "mergers of equals." In merger-of-equals combinations (MERGE_EQ), it is anticipated that more managers of target banks will survive in important roles than when the target is absorbed unequally. To test whether the preexisting relationship value of target customers is conserved more fully in merger-of-equal combinations, we define the indicator variable MERGE_EQ, which equals one in merger-of-equal deals and is zero otherwise.

\footnotetext{
${ }^{2}$ Firms that are customers of both the acquirer and target in a merger are classified as joint customers. Eliminating those firms that reappear in another merger does not materially affect our results.
} 
Mergers may expand an acquirer's share of existing markets and/or expand its product line or geographic footprint. Microeconomic theory indicates that a sizeable inmarket acquisition is likely to enhance a megabank's market power. Seven of the ten megamergers may be described as in-state acquisitions. Four of these show enough market overlap to be designated in-market. INMARKET takes on the value one for customers whose bank engages in an in-market merger; zero otherwise. We classify the other six combinations as either a market expansion (two cases), or a hybrid (four cases) based on the degree of deposit-market overlap. The final column of Table 1 lists states for which the combining banks each previously serviced at least one percent of deposits. Assuming that in individual state banking markets a bank's deposit and loan shares are highly correlated, we define OVERLAP to be a zero-one dummy that equals unity for customers located in states in which both partners' have at least one percent of the deposit market. For example, Norwest and Wells Fargo overlapped in Arizona, Nevada, and Texas.

\section{Customer Characteristics}

The empirical literature provides a guide in proxying for the competitiveness of each customer's funding environment (CREDIT_CONSTRAINED). In the macroeconomic literature on monetary policy and credit contractions, Gertler and Gilchrist (1994) and Kashyap, Stein, and Wilcox (1993) show that small firms and firms with limited access to credit markets are more sensitive to changes in available bank credit. In the merger literature, Strahan and Weston (1998); Berger et al (1998); Karceski, Ongena, and Smith (2005); and Sapienza (2002) show that firm size is among the best proxies for customer bargaining power. Kanatas and Qi (2003) also identify age. Houston and James (1996) and Detragiache, Garella, and Guison (2000) show that multiple relationships reduce hold-up costs and adverse-selection costs. While size, age, and relationships are important determinants of hold-up costs, Rajan and Zingales (1998) show that a firm must also have a financing need. Consistent with these prior studies, we constructed the following measures:

SIZE: Log of asset size (in \$million).

YRS: Log of number of years that the firm's stock had been trading publicly. 
MUL_REL: Zero-one dummy variable that equals one only for customers that have multiple banking relationships.

PUB_DEBT: Zero-one dummy variable that takes on the value one for corporations with public bonds outstanding.

EFN: External Financing Needs, (defined as planned investment minus internally generated funding).

Based on the joint findings of the previous literature, we define a corporation as potentially "credit-constrained" when it lies in the less-favorable tail of the distribution of each of the last five variables, that is when:

$$
\begin{aligned}
& \text { PUB_DEBT }=0, \\
& \text { YRS }<\log \text { of } 11 \text { years, } \\
& \text { SIZE }<\log \text { of } \$ 1 \text { Billion, } \\
& \text { EFN }>0, \text { and } \\
& \text { MUL_REL }=0 .
\end{aligned}
$$

A zero-one dummy variable (CREDIT_CONSTRAINED) assigns a value of one to customers that meet this five-way condition

\section{c. Sample Description}

Table 2 reports the mean value of all variables defined so far for the all-customer sample and for the subsamples of target and acquirer customers. ${ }^{3}$ The table also includes information on the median asset size and market capitalization of target, acquirer, and credit-constrained customers. Across the ten mergers, the respective sizes of the customer subsamples are: 1,016 target-bank customers; 1,292 acquirer customers; and 104 joint customers ( $4.7 \%$ of the aggregate sample). The number of customers of all kinds is $2,204(=1,016+1,292-104)$.

The six MERGE_EQ combinations account for 75.6 percent of total customers: 91.0 percent of target customers and 62.4 percent of acquirer customers. All but 11 of the joint observations occur in three merger-of-equals combinations: Chemical-Chase; First Union-Wachovia; and Fleet-BankBoston. In mergers of equals, joint customers may be better positioned to deal with the new management structure, but they also lose an

\footnotetext{
3 The Appendix describes in a reproducible way how these variables are constructed.
} 
alternative funding outlet. On the grounds that joint customers have lost an independent relationship, joint customers are pooled with target customers and eliminated from the acquirer subsample. However, except that this makes the subsamples closer in size, our qualitative findings are not sensitive to pooling decisions. ${ }^{4}$ In-market mergers account for 32.0 percent of the target sample and 27.6 percent of the acquirer sample. Target customers in overlapped markets constitute 10.9 percent of the target subsample and acquirer customers $8.4 \%$ of the acquirer subsample.

Although the means of all five customer characteristics differ significantly between the target and acquirer subsamples, only one merger characteristic (MERGE_EQ) does so at the 1 percent level. Assuming that customers of banks involved in mergers of equals are similar in their characteristics, when such customers account for $91 \%$ of the target subsample but only $62 \%$ of the acquirer subsample, average differences in favor of target customers may emerge. Our sample indicates that not only are target customers larger, but with respect to funding needs and alternative credit access, they seem more favorably situated on average than acquirer customers although the difference in the mean values of CREDIT_CONSTRAINED variable fails to reach statistical significance at the 1 percent level. Credit constrained customers, however, are of similar size across both subsamples.

\section{Methodology}

Our paper focuses on the effects that megamerger announcements have on the stock price of corporations that have an outstanding loan at either or both of the target bank and its acquirer. For individual customers, a market model is used to estimate and cumulate Day-0 and Day-1 "Abnormal Returns" to arrive at the cumulative abnormal returns $\left(\mathrm{CAR}_{\mathrm{i}}\right)$. Whether due to projected changes in $\mathrm{R}$ or bargaining power, these CARs should capture whatever net effect the merger has on a borrower's $\mathrm{R}_{\mathrm{C}}$. To investigate whether the effect is significant, $\mathrm{CAR}_{\mathrm{i}}$ is regressed upon proxies for the customer's relationship value $\left(\mathrm{R}_{\mathrm{i}}\right)$ and bargaining power $\left(\mathrm{BP}_{\mathrm{i}}\right)$.

\footnotetext{
${ }^{4}$ Pooling decisions are unlikely to impart a bias one way or the other. In addition to primarily being customers of banks involved in friendly mergers, joint customers are among the larger customers and by definition are not credit-constrained because they possess an additional relationship. They unlikely to be adversely affected by the merger whether they placed in the acquirer or target subsample. As a robustness check, we reran our regressions with a JOINT_CUST dummy. The dummy is always insignificant.
} 
Regression tests seek to approximate the following latent regression equation:

$$
\mathrm{CAR}_{\mathrm{i}}=\mathrm{a}_{\mathrm{i}}+\mathrm{b}_{\mathrm{i}} \mathrm{R}_{\mathrm{i}}+\mathrm{c}_{\mathrm{i}} \mathrm{BP}_{\mathrm{i}}+\mathrm{u}_{\mathrm{i}} .
$$

In estimating (2), the joint influence of $\mathrm{R}_{\mathrm{i}}$ and $\mathrm{BP}_{\mathrm{i}}$ is proxied by variables that exemplify merger and market characteristics that proxy for the post-merger disposition of target personnel (MERGE_EQ), for the extent to which the acquirers' product line and geographic footprint expand through in-market acquisitions (INMARKET), for deposit overlap (OVERLAP), and for the intensity of the competitive environment in which the customer must meet its financing needs (CREDIT_CONSTRAINED). The last variable combines effects related to a firm's need for financing and its access to credit.

Regression equations presented in our tables are of the form:

$$
\begin{aligned}
\text { CAR }_{\mathrm{i}}= & \mathrm{b}_{\mathrm{o}}+\mathrm{b}_{1} \text { MERGE_EQ }_{\mathrm{i}}+\mathrm{b}_{2} \text { INMARKET }_{\mathrm{i}}+\mathrm{b}_{3} \text { OVERLAP }_{\mathrm{i}}+\mathrm{b}_{4} \\
& \text { CREDIT_CONSTRAINED } \\
& +\mathrm{v}_{\mathrm{i}} .
\end{aligned}
$$

Our first strand of testing looks at whether differences exist in the means of CARs across subsamples composed of target and acquirer customers. The second and more important strand uses equation (3) to conduct two kinds of regression tests. Individual-coefficient ttests tell us whether we can reject the null hypothesis that some or all of the individual coefficients are zero. Covariance tests investigate whether particular coefficients differ across the customer subsamples.

\section{Results}

\section{a. First-round tests}

Table 3 presents the two-day mean CARs for all three customer groups. The table also reports these values for each of the individual megamergers.

Mean abnormal returns are statistically insignificant for all three customer groups. ${ }^{5}$ However, the proportion of CARs that are negative (47 percent in each case) differs significantly from 50 percent. No differences in the CARs are observed across the three customer groups.

Target customers are significantly affected in three cases, while effects on acquirer customers are never significant. Target customers benefited in the market-

\footnotetext{
${ }^{5}$ Averaging across the mergers — instead of across firms — also produces qualitatively similar results.
} 
expansion NationsBank/BankAmerica merger, and lost value in the largely in-market mergers of BankAmerica with Security Pacific and Fleet with BankBoston. ${ }^{6}$

\section{b. Regression tests}

Table 4 estimates equation (3) for the three sample groups. Model 1, using the entire customer sample, is our primary model. Controlling for merger and customer characteristics, the model shows that on average no difference emerges between acquirer, target, and joint customers in their response to the merger announcement: the dummy variables TARGET and JOINT_CUST are statistically insignificant. However, the model does show, through the interaction terms and customer-characteristic variables, that the customers' stake in banking megamergers varies with the merger's character and with the customer's economic circumstances.

These effects become apparent in Models 2 and 3 run on the target and acquirer customer subsamples respectively. Target customers have greater explainable crosssection variation than acquirer customers (R-squared of $4.57 \%$ for the targets compared to $1.67 \%$ for acquirers). Target customers suffer significantly if their bank is not treated as an equal and if they themselves are credit-constrained. Relative to other target customers, credit-constrained customers lost 2.0 percent of their value where their bank is not treated as an equal. ${ }^{7}$ Acquirer customers benefited from strictly in-market mergers (0.9 percent), but were harmed if the partners' larger geographic footprints materially overlap (-1.1 percent). Differences between the target and acquirer customer subsamples are confirmed through covariance tests involving the interaction terms in Model 1. Ftests reported at the bottom of the table establish that coefficients for the market-overlap, in-market, and credit-constrained indicators differ significantly between the target and acquired subsamples. ${ }^{8}$

\footnotetext{
${ }^{6}$ These results are robust to different market-portfolio construction methods (equally-weighted and valueweighted) and to an alternate standardization of abnormal returns (dividing the abnormal return by the standard deviation of the prediction error).

${ }^{7}$ The coefficient for TARGET * (1-MERGE_EQ) is -0.9 and that for TARGET * CREDIT_CONSTRAINED is -1.1.

${ }^{8}$ Introducing industry indicators in the models awards insignificant coefficients to the 1-digit SIC dummies. However, their inclusion decreases the standard error for the CREDIT_CONSTRAINED variable. Interacting TARGET and ACQUIRER with the constituents of CREDIT_CONSTRAINED as opposed to the composite CREDIT_CONSTRAINED variable supports the aggregation procedure.
} 
In Model 1, the positive slope of the SIZE coefficient assures us that, for largeenough size, adverse effects from other circumstances are overshadowed by benefits of size. This is our strongest and most important result. In fact, aggregating across the customer sample as a whole after multiplying each firm's cumulative abnormal return by its market capitalization reveals a $\$ 47$ billion increase in value for sample firms.

As Models 2 and 3 indicate, the positive coefficient on SIZE obtains significance only for target customers. For a target customer, the breakeven SIZE may be calculated as the value at which the positive impact of SIZE just equals the sum of the $-2.1 \%$ intercept and other relevant considerations. Using the coefficients from an unreported regression of target CARs on SIZE, the effect of the negative intercept washes out when SIZE equals about 7.4. This corresponds to a customer asset size of $\$ 1.65$ billion, which is greater than the $\$ 1.5$ billion asset size of the median target customer. Because firms represented in the CRSP and Compustat databases from which our target customers are drawn are disproportionately large, it appears that, in the typical megamerger, more than half of target customers suffer some discomfort.

Controlling for size and other characteristics, outstanding public bonds or multiple relationships also result in reduced customer value. This is possibly a reflection of the potential for megabanks to use their enhanced bargaining power to reduce the benefits customers previously derived from competing funding sources. As the banking industry continues to consolidate both nationally and globally, it will become increasingly important to size this discomfort and for society to consider explicitly whether and how to protect the interests of small and credit-constrained target customers in megamergers.

\section{Summary and Implications}

Acquirers absorb all tangible and intangible items on the economic balance sheet of target banks. Intangible items include charters, strategies, managerial skillsets, andas emphasized here - access to established customers. In any repeat business, customer relationships are important assets. This paper studies whether and when stockholders of customer firms worry about whether, under the new regime, their borrowing capacity might decline or credit terms become more rigorous. 
On average in the ten merger deals studied here, acquirer customers fared much better than customers of target banks. In our sample, target customers experienced significantly negative two-day returns in three circumstances. Small credit-constrained corporations lost on average $\$ 3$ million (or 1.23\%) in market cap. In unfriendly and inmarket combinations, adverse effects were more common. Stockholders of target customers lost an average of $\$ 46$ million $(0.86 \%)$ in unfriendly mergers and $\$ 31$ million $(0.32 \%)$ in in-market deals. ${ }^{9}$ Although regression analysis puts a finer edge on these differences, they are visible even in the market-value changes individual firms experience.

These findings are worrisome because the consolidation of large U.S. banks shows few signs of stopping. In 2004, Morgan acquired Bank One and Keycorp will join the list of top-ten banks if and when its in-market deal with CharterOne goes through. If bank consolidation intensifies capital constraints for small business, macroeconomic growth may be curtailed. Further, given that smaller companies create the largest portion of new jobs in our economy, our results suggest bank consolidation may adversely affect the job-creating capacity of the small-business sector. For this reason, we urge regulatory officials to investigate whether they can replicate our results across larger samples of post-1990 banking mergers and to place increased emphasis on how acquirers plan to preserve target-bank relationships.

\footnotetext{
${ }^{9}$ To estimate the market-value change for the sector, we take the average of the multiple of CAR times the market capitalization of the customer.
} 


\section{REFERENCES}

Bae, Kee-Hong, Jun-Koo Kang and Chan-Woo Lim, 2002. "The Value of Durable Bank Relationships: Evidence from Korean Banking Shocks," Journal of Financial Economics, 64, 181-214.

Berger, Allen N., Anthony Saunders, Joseph M. Scalise, and Gregory F. Udell, 1998. "The Effects of Bank Mergers and Acquisitions on Small Business Lending," Journal of Financial Economics, 50, 187-229.

Brewer, Elijah, Hesna Genay, William Hunter, and George Kaufman, 2003. "The Value of Banking Relationships During a Financial Crisis: Evidence from Failures of Japanese Banks," Journal of Japanese and International Economies 17, 233-262.

Degryse, Hans, Nancy Masschelein, and Janet Mitchell, 2003.SMEs and Bank Lending Relationships: The Impact of Mergers," National Bank of Belgium Working Paper.

Detragiache, Enrica., Paolo Garella, and Luigi Guiso, 2000. "Multiple versus single banking relationships: Theory and evidence," Journal of Finance, 55, 1133-62.

Diamond, Douglas W., 1984. "Financial Intermediation and Delegated Monitoring," Review of Economic Studies, 51 (April), 393-414.

Focarelli, Dario, Fabio Panetta, and Carmelo Salleo, 2002. "Why Do Banks Merge?" Journal of Money, Credit, and Banking, 34, 1047-1066.

Gande, Amar, Manju Puri, Anthony Saunders, and Ingo Walter, 1997. "Bank underwriting of debt securities: Modern evidence," Review of Financial Studies $10,1175-1202$.

Gertler, Mark and Simon Gilchrist, 1994. "Monetary Policy, Business Cycles, and the Behavior of Small Manufacturing Firms," Quarterly Journal of Economics, 109, 309-340.

Houston, Joel and Michael Ryngaert. 1994. "The overall gains from large bank mergers." Journal of Banking and Finance, 18, 1155-1176.

Houston, Joel and Christopher James. 1996. "Bank information monopolies and the mix of private and public debt claims," The Journal of Finance, 51, 1863-1889.

Houston, Joel, Christopher James, and Michael Ryngaert, 2001. "Where do merger gains come from? Bank mergers from the perspective of insiders and outsiders."

Journal of Financial Economics, 60, 285-331.

Kanatas, George and Jianping Qi, 2003. "Integration of lending and underwriting: Implications of scope economies," The Journal of Finance, 58 (June), 1167-91. 
Kane, Edward J., 2000. "Incentives for Banking Megamergers: What Motives Might Regulators Infer from Event-Study Evidence?" Journal of Money Credit and Banking, 32, 671-701

Kane, Edward J. and Burton G. Malkiel, 1965. "Bank Portfolio Allocation, Deposit Variability, and the Availability Doctrine," Quarterly Journal of Economics, 79, 113-134.

Karceski, Jason, Steven Ongena, and David C. Smith, 2005. "The Impact of Bank Consolidation on Commercial Welfare," Journal of Finance, forthcoming.

Kashyap, Anil, Jeremy Stein, and David Wilcox, 1993. "Mondetary Policy and Credit Conditions: Evidence from the Composition of External Finance," American Economic Review, 83, 78-98.

Narayanan, Rajesh P., Kasturi P. Rangan, and Nanda K. Rangan, 2004. "The role of syndicate structure in bank underwriting", Journal of Financial Economics 72, 555-580.

Ongena, Steven, David C. Smith, and Dag Michalsen, 2003. "Firms and Their Distressed Banks: Lessons from the Norwegian Banking Crises," Journal of Financial Economics, 67, 81-112.

Penas, Maria F., and Haluk Unal, 2004. "Gains In Bank Mergers: Evidence from the Bond Markets," Journal of Financial Economics, 74, 149-179.

Rajan, Raghuram G. and Luigi Zingales, 1998. "Financial dependence and growth," The American Economic Review, 88, 559-86.

Sapienza, Paola, 2002. "The Effects of Banking Mergers on Loan Contracts," Journal of Finance, 57, 329-67.

Sapsford, Jonathon, 2004. "Executives See Rise in Tying Loans to Other Fees," Wall Street Journal, June 9, A1.

Slovin, Myron B., Marie E. Sushka, and John A. Polonchek, 1993. "The Value of Bank Durability: Borrowers as Bank Stakeholders," Journal of Finance, 48, 247-66.

Strahan, Philip E., and James P. Weston, 1998. "Small Business Lending and the Changing Structure of the Banking Industry," Journal of Banking and Finance, $22,821-45$.

Yasuda, Ayako, 2005, "Do bank relationships affect the firm's underwriter choice in the corporate bond underwriting market?" Journal of Finance, forthcoming. 
Draft: 03-28-05

Table 1: Ten Largest Combinations of U.S. Banks, 1991-2001

\begin{tabular}{|c|c|c|c|c|c|c|}
\hline Acquirer/Target & $\begin{array}{c}\text { Announcement } \\
\text { Date }\end{array}$ & $\begin{array}{c}\text { Completion/ } \\
\text { Termination } \\
\text { Date }\end{array}$ & $\begin{array}{l}\text { Merger of } \\
\text { equals } \\
\text { Yes/No } \\
\end{array}$ & $\begin{array}{l}\text { In-state } \\
\text { buyer } \\
\text { Yes/No }\end{array}$ & Geographic Character & $\begin{array}{l}\text { States with non-negligible } \\
\text { market overlap (both banks } \\
>1 \% \text { deposits) }\end{array}$ \\
\hline BankAmerica Corp./ Security Pacific Corporation & 08/12/1991 & $04 / 22 / 1992$ & No & Yes & In-Market & CA, WA \\
\hline Chemical Banking Corporation/ Chase Manhattan Corp. & $08 / 28 / 1995$ & 04/01/1996 & Yes & Yes & In-Market & NY \\
\hline Wells Fargo \& Co./ First Interstate Bancorp & $01 / 24 / 1996$ & 04/01/1996 & No & Yes & In-Market & $\mathrm{CA}$ \\
\hline Bank One Corp./ First Chicago NBD Corp. & 04/13/1998 & $10 / 02 / 1998$ & Yes & Yes & Partial Overlap & IN, IL \\
\hline NationsBank Corp./ BankAmerica Corp. & 04/13/1998 & 09/30/1998 & Yes & No & Market Expansion & \\
\hline Norwest Corp./ Wells Fargo \& Co. & 06/08/1998 & $11 / 02 / 1998$ & Yes & No & Partial Overlap & $\mathrm{AZ}, \mathrm{NV}, \mathrm{TX}$ \\
\hline Fleet Financial Group/ BankBoston Corp. & 03/14/1999 & 09/30/1999 & Yes & Yes & In-Market & MA, RI, CT, NH \\
\hline Chase Manhattan Corp./ J.P. Morgan \& Co. & $09 / 13 / 2000$ & $12 / 31 / 2000$ & No & Yes & Market Expansion & NY \\
\hline Firstar Corp./ U.S. Bancorp & $10 / 04 / 2000$ & $02 / 27 / 2001$ & No & No & Partial Overlap & IA \\
\hline First Union Corp./ Wachovia Corp. & $04 / 15 / 2001$ & $09 / 04 / 2001$ & Yes & Yes & Partial Overlap & $\mathrm{NC}, \mathrm{GA}, \mathrm{VA}$ \\
\hline
\end{tabular}


Table 2: Summary Statistics on Variables Used in Subsequent Regression Tests

Variable definitions may be found in the Appendix.

The difference in means is tested using a t-test, and the difference in medians using a Wilcoxon rank sum test.

\begin{tabular}{|c|c|c|c|c|c|}
\hline Variable & $\begin{array}{c}\text { All } \\
\text { Customers } \\
\end{array}$ & $\begin{array}{c}\text { Target } \\
\text { Customers } \\
\text { (includes } \\
\text { Joint } \\
\text { Customers) }\end{array}$ & $\begin{array}{c}\text { Exclusive } \\
\text { Acquirer } \\
\text { Customers }\end{array}$ & $\begin{array}{c}\text { P-Values } \\
\text { Differences } \\
\text { in Means }\end{array}$ & $\begin{array}{c}\text { P-Values } \\
\text { Differences in } \\
\text { Medians } \\
\end{array}$ \\
\hline No. of Observations & 2204 & 1016 & 1188 & $\mathrm{~N} / \mathrm{A}$ & $\mathrm{N} / \mathrm{A}$ \\
\hline JOINT_CUST & $4.67 \%$ & $10.14 \%$ & $\mathrm{~N} / \mathrm{A}$ & $\mathrm{N} / \mathrm{A}$ & $\mathrm{N} / \mathrm{A}$ \\
\hline \multicolumn{6}{|c|}{ Merger and Market Characteristics } \\
\hline $\begin{array}{l}\text { MERGE_EQ } \\
\text { INMARKET } \\
\text { OVERLAP }\end{array}$ & $\begin{array}{c}75.59 \% \\
29.63 \% \\
9.57 \%\end{array}$ & $\begin{array}{l}91.04 \% \\
31.99 \% \\
10.93 \%\end{array}$ & $\begin{array}{c}62.37 \% \\
27.61 \% \\
8.42 \%\end{array}$ & $\begin{array}{l}0.0001 \\
0.0248 \\
0.0461\end{array}$ & $\begin{array}{l}0.0001 \\
0.0249 \\
0.0462\end{array}$ \\
\hline \multicolumn{6}{|c|}{ Customer Characteristics } \\
\hline PUB_DEBT & $56.76 \%$ & $62.40 \%$ & $51.94 \%$ & 0.0001 & 0.0001 \\
\hline $\mathrm{SIZE}$ & 7.1370 & 7.3064 & 6.9921 & 0.0001 & 0.0001 \\
\hline YRS & 2.2421 & 2.3319 & 2.1654 & 0.0001 & 0.0001 \\
\hline $\mathrm{EFN}$ & 0.0225 & -0.1330 & 0.1556 & 0.0001 & 0.0001 \\
\hline MUL REL & $60.44 \%$ & $65.75 \%$ & $55.89 \%$ & 0.0001 & 0.0001 \\
\hline CREDIT_CONNSTRAINED & $7.35 \%$ & $6.00 \%$ & $8.50 \%$ & 0.0251 & 0.0251 \\
\hline
\end{tabular}

Descriptive Statistics for Customers (median values in parentheses)

\begin{tabular}{|c|c|c|c|c|c|}
\hline Sales (MM\$) & $\begin{array}{l}4,657 \\
(994)\end{array}$ & $\begin{array}{c}6,216 \\
(1,375)\end{array}$ & $\begin{array}{l}3,321 \\
(716)\end{array}$ & 0.0001 & 0.0001 \\
\hline Market Value Assets (MM\$) & $\begin{array}{c}5,139 \\
(1,285)\end{array}$ & $\begin{array}{c}6,379 \\
(1,695)\end{array}$ & $\begin{array}{c}4,078 \\
(1,096)\end{array}$ & 0.0001 & 0.0001 \\
\hline Market Cap (MM\$) & $\begin{array}{l}1,363 \\
(942)\end{array}$ & $\begin{array}{l}1,488 \\
(414)\end{array}$ & $\begin{array}{l}1,256 \\
(326)\end{array}$ & 0.3152 & 0.0099 \\
\hline Years on CRSP & $\begin{array}{c}13.3 \\
(11.0)\end{array}$ & $\begin{array}{l}14.3 \\
(13)\end{array}$ & $\begin{array}{l}12.5 \\
(10)\end{array}$ & 0.0001 & 0.0001 \\
\hline
\end{tabular}

For Subset of Credit-Constrained Customers (median values in parentheses)

Market Cap (MM\$) 77

(33)
83

(21)
73

(38)
0.5298

0.5672 
Table 3: Mean Cumulative Abnormal Returns Experienced by Customers of the Target and Acquirer in Individual Megamergers

The z-statistic is determined as, $\left(G-N_{p}\right) / \sqrt{N_{p}(1-P)}$, where $\mathrm{G}$ is the number of positive parameter estimates, $\mathrm{N}_{\mathrm{p}}$ is the total number of parameter estimates, and $\mathrm{P}=.50$ (the probability of a positive estimate). $*, * *, * * *$ represent significance at 10,5 , and 1 percent, respectively.

\begin{tabular}{|c|c|c|c|c|}
\hline & $\begin{array}{l}\text { All } \\
\text { Customers }\end{array}$ & $\begin{array}{l}\text { Target } \\
\text { Customers } \\
\text { (includes } \\
\text { joint } \\
\text { customers) } \\
\end{array}$ & $\begin{array}{l}\text { Acquirer } \\
\text { Customers } \\
\text { (excludes } \\
\text { joint } \\
\text { customers) } \\
\end{array}$ & $\begin{array}{l}\text { Difference } \\
\text { and } \\
\text { t-test for } \\
\text { Difference }\end{array}$ \\
\hline \multicolumn{5}{|c|}{ All mergers } \\
\hline $\begin{array}{l}\text { Number of Firms } \\
\text { Average CAR }(0,1) \text { across all firms } \\
\text { t-stat } \\
\text { Percent negative } \\
\text { Z-stat }\end{array}$ & $\begin{array}{l}2204 \\
-0.07 \% \\
-0.30 \\
46.82 \% \\
2.98\end{array}$ & $\begin{array}{l}1016 \\
-0.03 \% \\
-0.93 \\
46.85 \% \\
2.10\end{array}$ & $\begin{array}{l}1188 \\
-0.11 \% \\
-0.45 \\
46.80 \% \\
2.20\end{array}$ & $\begin{array}{l}0.08 \% \\
0.99\end{array}$ \\
\hline \multicolumn{5}{|c|}{ For each merger } \\
\hline $\begin{array}{l}\text { BankAmerica Corp./ Security Pacific Corp. } \\
\text { Number of Firms } \\
\text { CAR }(0,1) \\
\text { t-stat }\end{array}$ & $\begin{array}{l}69 \\
-0.13 \% \\
(-0.19)\end{array}$ & $\begin{array}{l}28 \\
-0.40 \% \\
(-0.22)\end{array}$ & $\begin{array}{l}41 \\
0.05 \% \\
(0.42)\end{array}$ & $\begin{array}{l}-0.45 \\
(-0.44)\end{array}$ \\
\hline $\begin{array}{l}\text { Chemical Banking Corp./ Chase Manhattan Corp. } \\
\text { Number of Firms } \\
\text { CAR }(0,1) \\
\text { t-stat }\end{array}$ & $\begin{array}{l}202 \\
0.20 \% \\
(1.15)\end{array}$ & $\begin{array}{l}58 \\
-0.33 \% \\
(-0.19)\end{array}$ & $\begin{array}{l}144 \\
0.41 \% \\
(1.48)\end{array}$ & $\begin{array}{l}-0.74 \% \\
(-0.95)\end{array}$ \\
\hline $\begin{array}{l}\text { Wells Fargo \& Co./ First Interstate Bancorp } \\
\text { Number of Firms } \\
\text { CAR }(0,1) \\
\text { t-stat }\end{array}$ & $\begin{array}{l}71 \\
-0.16 \% \\
(-1.32)\end{array}$ & $\begin{array}{l}37 \\
-1.25 \% \\
(-2.82)^{* * *}\end{array}$ & $\begin{array}{l}34 \\
1.04 \% \\
(1.03)\end{array}$ & $\begin{array}{l}-2.29 \% \\
(-2.70)^{* * *}\end{array}$ \\
\hline $\begin{array}{l}\text { Bank One Corp./ First Chicago NBD Corp. } \\
\text { Number of Firms } \\
\text { CAR }(0,1) \\
\text { t-stat }\end{array}$ & $\begin{array}{l}275 \\
0.16 \% \\
(1.02)\end{array}$ & $\begin{array}{l}188 \\
0.25 \% \\
(1.12)\end{array}$ & $\begin{array}{l}87 \\
-0.03 \% \\
(-0.16)\end{array}$ & $\begin{array}{l}0.28 \% \\
(0.50)\end{array}$ \\
\hline $\begin{array}{l}\text { NationsBank Corp./ BankAmerica Corp. } \\
\text { Number of Firms } \\
\text { CAR }(0,1) \\
\text { t-stat }\end{array}$ & $\begin{array}{l}544 \\
0.08 \% \\
(1.26)\end{array}$ & $\begin{array}{l}316 \\
0.23 \% \\
(2.42)^{* *}\end{array}$ & $\begin{array}{l}228 \\
-0.12 \% \\
(-0.90)\end{array}$ & $\begin{array}{l}0.35 \% \\
(2.25)^{* *}\end{array}$ \\
\hline $\begin{array}{l}\text { Norwest Corp./ Wells Fargo \& Co. } \\
\text { Number of Firms } \\
\text { CAR }(0,1) \\
\text { t-stat }\end{array}$ & $\begin{array}{l}89 \\
-0.16 \% \\
(-0.67)\end{array}$ & $\begin{array}{l}63 \\
-0.38 \% \\
(-1.01)\end{array}$ & $\begin{array}{l}26 \\
0.35 \% \\
(0.35)\end{array}$ & $\begin{array}{l}-0.73 \% \\
(-0.84)\end{array}$ \\
\hline $\begin{array}{l}\text { Fleet Financial Group/ BankBoston Corp. } \\
\text { Number of Firms } \\
\text { CAR }(0,1) \\
\text { t-stat }\end{array}$ & $\begin{array}{l}311 \\
-0.73 \% \\
(-2.04)^{* *}\end{array}$ & $\begin{array}{l}131 \\
-0.98 \% \\
(-2.00)^{* *}\end{array}$ & $\begin{array}{l}180 \\
-0.55 \% \\
(-0.98)\end{array}$ & $\begin{array}{l}-0.43 \% \\
(-0.89)\end{array}$ \\
\hline $\begin{array}{l}\text { Chase Manhattan Corp./ J.P. Morgan \& Co. } \\
\text { Number of Firms } \\
\text { CAR }(0,1) \\
\text { t-stat }\end{array}$ & $\begin{array}{l}368 \\
-0.44 \% \\
(-1.84)\end{array}$ & $\begin{array}{l}13 \\
-1.06 \% \\
(-0.90)\end{array}$ & $\begin{array}{l}355 \\
-0.42 \% \\
(-1.70)\end{array}$ & $\begin{array}{l}0.64 \% \\
(-0.56)\end{array}$ \\
\hline $\begin{array}{l}\text { Firstar Corp./ U.S. Bancorp } \\
\text { Number of Firms } \\
\text { CAR }(0,1) \\
\text { t-stat }\end{array}$ & $\begin{array}{l}30 \\
0.56 \% \\
(1.06)\end{array}$ & $\begin{array}{l}6 \\
0.15 \% \\
(0.13)\end{array}$ & $\begin{array}{l}24 \\
0.67 \% \\
(1.12)\end{array}$ & $\begin{array}{l}0.52 \% \\
(0.39)\end{array}$ \\
\hline $\begin{array}{l}\text { First Union Corp./ Wachovia Corp. } \\
\text { Number of Firms } \\
\text { CAR }(0,1) \\
\text { t-stat }\end{array}$ & $\begin{array}{l}245 \\
0.49 \% \\
(2.10) * *\end{array}$ & $\begin{array}{l}73 \\
0.69 \% \\
(1.53)\end{array}$ & $\begin{array}{l}172 \\
0.40 \% \\
(1.51)\end{array}$ & $\begin{array}{l}0.29 \% \\
(0.46)\end{array}$ \\
\hline
\end{tabular}


Table 4 Cross-sectional analysis of returns

The endogenous variable is the percentage cumulative abnormal return, $\operatorname{CAR}(0,1)$, for loan customers surrounding the announcement of a bank merger. Variables definitions are specified in the Appendix. tvalues are shown in parentheses below each coefficient. ${ }^{*}, * * * * *$ represent significance at 10,5 , and 1 percent, respectively.

\begin{tabular}{|c|c|c|c|}
\hline & $\begin{array}{c}\text { All } \\
\text { Customers }\end{array}$ & $\begin{array}{c}\text { Target } \\
\text { Customers } \\
\text { (includes Joint } \\
\text { customers) }\end{array}$ & $\begin{array}{l}\text { Acquirer } \\
\text { Customers } \\
\text { (excludes joint } \\
\text { customers) }\end{array}$ \\
\hline Intercept & $\begin{array}{c}-1.441 \% \\
(-3.29) * * *\end{array}$ & $\begin{array}{c}-2.106 \% \\
(-3.42) * * *\end{array}$ & $\begin{array}{c}-0.817 \% \\
(-1.34)\end{array}$ \\
\hline TARGET & $\begin{array}{l}0.113 \\
(0.54)\end{array}$ & & \\
\hline JOINT_CUST & $\begin{array}{l}0.421 \\
(0.99)\end{array}$ & $\begin{array}{l}0.442 \\
(1.12)\end{array}$ & \\
\hline$($ TARGET) $*(1$ - MERGE_EQ $)$ & $\begin{array}{l}-0.726 \\
(-1.50)\end{array}$ & $\begin{array}{c}-0.888 \\
(-1.93)^{*}\end{array}$ & \\
\hline$($ ACQUIRER) $*(1$ - MERGE_EQ) & $\begin{array}{l}-0.322 \\
(-1.43)\end{array}$ & & $\begin{array}{l}-0.218 \\
(-0.91)\end{array}$ \\
\hline$($ TARGET) $*$ OVERLAP & $\begin{array}{l}0.347 \\
(0.85)\end{array}$ & $\begin{array}{l}0.053 \\
(0.14)\end{array}$ & \\
\hline (ACQUIRER) * OVERLAP & $\begin{array}{c}-1.052 \\
(-2.78)^{* * *}\end{array}$ & & $\begin{array}{c}-1.131 \\
(-2.62)^{* * *}\end{array}$ \\
\hline$($ TARGET) $*$ INMARKET & $\begin{array}{l}-0.348 \\
(-0.88)\end{array}$ & $\begin{array}{l}-0.368 \\
(-0.97)\end{array}$ & \\
\hline (ACQUIRER) * INMARKET & $\begin{array}{c}0.747 \\
(2.49)^{* *}\end{array}$ & & $\begin{array}{c}0.873 \\
(2.64)^{* * *}\end{array}$ \\
\hline$($ TARGET) $*$ CREDIT_CONSTRAINED & $\begin{array}{c}-0.955 \\
(-1.80)^{*}\end{array}$ & $\begin{array}{c}-1.125 \\
(-2.04)^{* *}\end{array}$ & \\
\hline$($ ACQUIRER) $*$ CREDIT_CONSTRAINED & $\begin{array}{l}0.412 \\
(0.98)\end{array}$ & & $\begin{array}{l}0.449 \\
(0.96)\end{array}$ \\
\hline SIZE & $\begin{array}{c}0.294 \\
(4.39)^{* * *}\end{array}$ & $\begin{array}{c}0.528 \\
(5.33)^{* * *}\end{array}$ & $\begin{array}{l}0.138 \\
(1.51)\end{array}$ \\
\hline PUB_DEBT & $\begin{array}{c}-0.548 \\
(-2.55)^{* *}\end{array}$ & $\begin{array}{l}-0.549 \\
(-1.73)^{*}\end{array}$ & $\begin{array}{c}-0.592 \\
(-2.04)^{* *}\end{array}$ \\
\hline MUL_REL & $\begin{array}{l}-0.211 \\
(-1.09)\end{array}$ & $\begin{array}{c}-1.100 \\
(-3.80)^{* * *}\end{array}$ & $\begin{array}{l}0.337 \\
(1.30)\end{array}$ \\
\hline EFN & $\begin{array}{l}-0.048 \\
(-1.14)\end{array}$ & $\begin{array}{l}-0.017 \\
(-0.27)\end{array}$ & $\begin{array}{l}-0.061 \\
(-1.07)\end{array}$ \\
\hline YRS & $\begin{array}{l}-0.118 \\
(-1.26)\end{array}$ & $\begin{array}{c}-0.244 \\
(-1.79)^{*}\end{array}$ & $\begin{array}{l}-0.056 \\
(-0.44)\end{array}$ \\
\hline $\begin{array}{l}\text { Number of Observations } \\
\text { R-squared } \\
\text { Adjusted R-squared } \\
\text { P-value for F-stat }\end{array}$ & $\begin{array}{c}2204 \\
0.0212 \\
0.0145 \\
0.0001 \\
\end{array}$ & $\begin{array}{l}1016 \\
0.0457 \\
0.0362 \\
0.0001 \\
\end{array}$ & $\begin{array}{l}1188 \\
0.0167 \\
0.0092 \\
0.0184 \\
\end{array}$ \\
\hline $\begin{array}{l}\text { F-tests of Coefficients } \\
\text { (TARGET)*(1 - MERGE_EQ) = } \\
\text { (ACQUIRER)*(1 - MERGE_EQ) } \\
(\text { TARGET)*OVERLAP = } \\
\text { (ACQUIRER) OVERLAP } \\
(\text { TARGET)*INMARKET = } \\
\quad \text { (ACQUIRER)*INMARKET } \\
(\text { TARGET)*CREDIT_CONSTRAINED = } \\
\text { (ACQUIRER)*CREDIT CONSTRAINED }\end{array}$ & $\begin{array}{c}\text { p-values } \\
0.4593\end{array}$ & & \\
\hline
\end{tabular}


Draft: $03-28-05$

\section{APPENDIX EXPLAINING THE PRECISE CONSTRUCTION OF VARIABLES FROM COMPUSTAT, CRSP, FEDERAL RESERVE, LPC, and SNL DATABASE SOURCES}

Variable Name

$\operatorname{CAR}(0,1)$

PUB_DEBT

SIZE

YRS

EFN

MUL_REL

MERGE_EQ

OVERLAP

INMARKET

JOINT_CUST

TARGET

ACQUIRER

CREDIT_CONSTRAINED

\section{Description}

The percentage cumulative abnormal return for the 2-day event period combining the day of the announcement and the day following the announcement $[\operatorname{CAR}(0,1)]$. For all abnormal returns, the estimation period is the 200 days ending 11 days prior to the announcement.

An indicator variable that equals 1 if the firm has public debt outstanding and is 0 otherwise (based on Compustat data).

The natural $\log$ of the market value of assets in $\$$ millions for the firm. From Compustat, the market value of assets $=$ data $6-$ data 60 + market capitalization - data50. All outlying values are winsorized at the $5^{\text {th }}$ or $95^{\text {th }}$ percentile.

The log of the number of years that the company has been listed on either the NYSE, AMEX, or NASDAQ, where the maximum number of years was set at 25 (based on CRSP data).

The average external finance needs during the last 3 years - based on the method developed by Rajan and Zingales (1998). If less than 3 years of data are available, we employ the available data. From Compustat, $\mathrm{EFN}=($ data128 $-($ data1 $8+$ data14 $)+($ data3 data3a) + (data2 - data2a) - (data70 - data70a) - (data71 data71a))/data128. Outlying three-year average values are winsorized at the $5^{\text {th }}$ and $95^{\text {th }}$ percentile.

An indicator variable that equals 1 if the firm has more than one banking relationship as shown in the LPC database, and is 0 otherwise.

An indicator variable that equals 1 if the merger was a merger of equals as defined in SNL DataSource and presented in Table 1; equals 0 otherwise.

An indicator variable equal to 1 for customers headquartered in one of the states that show significant overlap in market share as defined in the Federal Reserve Database and presented in Table 1; equals 0 otherwise.

An indicator variable equal to 1 if the merger was defined as an inmarket merger, as presented in Table 1; equals 0 otherwise.

An indicator variable that takes on the value of 1 if the firm is a customer of both the target and the acquirer bank, and is 0 otherwise.

An indicator variable that equals 1 if the firm is a customer of the target bank, and is 0 otherwise.

A zero-one dummy variable that takes on the value of 1 for customers of the acquiring institution, and is 0 otherwise.

An indicator variable that takes on the value of 1 if the firm is credit-constrained. We define credit-constrained customers from Compustat: if $\mathrm{YRS}<\mathbf{1 1}$ and $\mathrm{SIZE}<\mathbf{5 0 0}$ and $\mathrm{EFN}>\mathbf{. 0 0 1}$, PUB_DEBT $=\mathbf{0}$, and MUL_REL $=\mathbf{0}$; otherwise its value is 0 . 